\title{
ANALYSIS OF PATH DEPENDENCE OF INFRASTRUCTURAL ECONOMIC SECTORS DEVELOPMENT IN RESOURCE-EXTRACTION REGION (CASE STUDY OF KHANTY-MANSI AUTONOMOUS OKRUG - YUGRA)
}

\author{
Bolshanik P.V. \\ Yugra State University, \\ Khanty-Mansiysk, 628011, Russia \\ Sannikov D.V \\ Yugra State University, \\ Khanty-Mansiysk, 628011, Russia
}

\author{
Kniazeva V.B. \\ Yugra State University, \\ Khanty-Mansiysk, 628011, Russia \\ Tatiankin V.M. \\ Yugra State University, \\ Khanty-Mansiysk, 628011, Russia
}

\begin{abstract}
The paper reflects research findings of the path dependence of infrastructural economic sectors in the KhantyMansi Autonomous Okrug - Yugra - by performing an autocorrelation analysis. The authors analyze the path dependence of infrastructure economic sectors of the northern resource-extraction region resulted in detecting the dependence on last years' indicators, as well as a 3-year negative internal cycle in the transport industry, and a 4-year cycle in the financial industry, while no obvious internal development cycles have been observed in the "Information and Communication Technologies" and "Trade and Small Business" industries. It has been revealed that the path dependence of economic sectors in the Khanty-Mansi Autonomous Okrug - Yugra - causes problems for economic reforming and diversification.
\end{abstract}

Keywords- Evolution of economic industries, resourceextraction region, infrastructure economic sectors, autocorrelation analysis, path dependence.

\section{INTRODUCTION}

The relevance of this study is that the region's economic development is determined not only by economic and technological factors but by institutional ones as well. Institutional analysis is one of the most requested methodological approaches to study regional specifics, as it expands the object of regional analysis due to incorporating new phenomena and events into it, which never before have been the object of regional analysis, as well as it recognizes the existence of regional modern path dependence [4]. This dependence is especially pressing in the Khanty-Mansi Autonomous Okrug - Yugra (hereinafter KMAO - Yugra), being highly dependent on resource extraction economy and global market environment for hydrocarbon commodities.
At present, studying a path dependence concept is becoming more relevant, which states that minor random events can set institutional development on an inefficient path [10]. Douglass North is believed to be the originator of this scientific direction, winning the 1993 Nobel Memorial Prize in Economic Sciences for his constructive application of the comparative institutional analysis in his works on economic history [14]. The current state of the institutional system depends on its development over previous periods, curbing freedoms of arbitrary choice, import or institution design and may lead to stabilizing inefficient institutional systems, or "institutional trap" [8]. This problem is basically considered in the context of Russia's economic development at large, but research to define development dependence of economic sectors in the northern resource-extraction region is still scarce.

The objective is to address the following scientific problems: what development path of infrastructural economic sectors in the Khanty-Mansi Autonomous Okrug was and how this path affected their further development.

The potential for using the research findings to address applied problems involves a revealed degree of path dependence of the region's economic evolution, allowing one to define its development inertia and, accordingly, adjust the expected results from infrastructure and institutional reforms.

\section{PATH DEPENDENCE THEORY AND AUTOCORRELATION ANALYSIS METHOD}

The theory of path dependence is applied in many economic domains. Thus, Thomas Brekke pursues a study [11] on the regional path dependence theory affecting the industrial evolution in a non-migration region characterized by a specialized cluster of high-tech companies. Path dependence is reflected in economic geography: regional development 
prospects are directly related to historical dynamics of economic landscapes, i.e. they are "place-dependent" [13]. Russian scientists [7] apply this theory to analyze the potential for the regional construction development in post-Soviet states, as well as to assess its impact on the national economic growth strategy [9].

Autocorrelation is one of the basic methods to study trends and cyclic components of time series [15]. Time series data, in contrast to ordinary sample data, characterize an object in question at different moments or periods of time, and an autocorrelation function shows autocorrelation dependence on a lag value [1], i.e. there is a dependence between historical data and future levels of time series [5].

Autocorrelation is applied in various economic fields: for analyzing stock markets [5], for determining return of credit institutions [6]. Also, the autocorrelation method is utilized in such scientific fields as microbiology to study relationships between chromosomes position and gene expression patterns [12], in medicine to detect spatial anomalies (hotspots) in regions of disease [16] etc. In this study, the autocorrelation method was employed to study path dependence of economic sectors in the resource-extraction region.

A correlation coefficient value $r(\tau)$ defines how strong the statistical association is between levels of time series shifted by $\mathrm{t}$ time units. A time lag defines the order of autocorrelation coefficients [2]. (1):

The autocorrelation coefficient is calculated by the formula

$$
r(\tau)=\frac{(n-\tau) \sum_{t=1}^{n-\tau} y_{\tau} y_{t+\tau}-\sum_{t=1}^{n-\tau} y_{t} \sum_{t=1}^{n-\tau} y_{t+\tau}}{\sqrt{\left[(n-\tau) \sum_{t=1}^{n-\tau} y_{t^{2}}-\left(\sum_{t=1}^{n-\tau} y_{t}\right)^{2}\right]\left[(n-\tau) \sum_{t=1}^{n-\tau} y_{t+\tau}^{2}-\left(\sum_{t=1}^{n-\tau} y_{t+\tau}\right)^{2}\right]}}
$$

\section{ANALYSIS OF THE PATH DEPENDENCE OF INFRASTRUCTURAL ECONOMIC SECTORS IN THE NORTHERN RESOURCE-EXTRACTION REGION}

Regional economic development is deemed to be impossible without an appropriate infrastructure complex, which is divided into 2 independent parts: a communication system that includes both transport and communications and tertiary industries (trade and catering, housing maintenance and public utilities, science and education, finance and credit, etc).

Major tasks of the transport infrastructure are to establish conditions for public and cargo transportation, transport service integrity control for economic entities of production and nonproductive sectors, as well as for the region's population. Path dependence analysis of the transport industry is presented in Table 6.

TABLE I. AUTOCORRELATION COEFFICIENTS BY KEY INDICATORS FOR TRANSPORT SECTOR

\begin{tabular}{|c|c|c|c|c|c|c|c|c|c|c|}
\hline Indicators & \multicolumn{4}{|c|}{ By absolute value of } & \multicolumn{4}{c|}{ By incremental value of } \\
indicator with a shift (lag) & \multicolumn{3}{c|}{ indicator with a shift (lag) } \\
\cline { 2 - 10 } & $\begin{array}{c}\mathbf{1} \\
\text { year }\end{array}$ & $\begin{array}{c}\mathbf{2} \\
\text { years }\end{array}$ & $\begin{array}{c}\mathbf{3} \\
\text { years }\end{array}$ & $\begin{array}{c}\mathbf{4} \\
\text { years }\end{array}$ & $\begin{array}{c}\mathbf{5} \\
\text { years }\end{array}$ & $\begin{array}{c}\mathbf{1} \\
\text { year }\end{array}$ & $\begin{array}{c}\mathbf{2} \\
\text { years }\end{array}$ & $\begin{array}{c}\mathbf{3} \\
\text { years }\end{array}$ & $\begin{array}{c}\mathbf{4} \\
\text { years }\end{array}$ & $\begin{array}{c}\mathbf{5} \\
\text { years }\end{array}$ \\
\hline \multirow{2}{*}{ Value added } & 0,95 & 0,95 & 0,97 & 0,94 & 0,92 & - & $-0,28$ & 0,33 & 0,07 & $-0,15$ \\
\hline
\end{tabular}

\begin{tabular}{|c|c|c|c|c|c|c|c|c|c|c|}
\hline $\begin{array}{l}\text { Number } \\
\text { economic } \\
\text { entities }\end{array}$ & 1,00 & 0,99 & 0,97 & 0,97 & 0,97 & 0,64 & 0,35 & 0,00 & $-0,60$ & $-0,37$ \\
\hline $\begin{array}{l}\text { Number } \\
\text { employed }\end{array}$ & 0,36 & $-0,25$ & $-0,03$ & 0,15 & 0,20 & 0,08 & $-0,77$ & $-0,51$ & 0,25 & 0,67 \\
\hline $\begin{array}{l}\text { Average } \\
\text { monthly } \\
\text { nominal wage }\end{array}$ & 1,00 & 0,99 & 0,99 & 1,00 & 1,00 & 0,03 & $-0,39$ & $-0,58$ & 0,40 & 0,25 \\
\hline $\begin{array}{l}\text { Fixed assets } \\
\text { costs }\end{array}$ & 0,90 & 0,84 & 0,81 & 0,73 & 0,70 & 0,41 & $-0,11$ & 0,11 & $-0,08$ & $-0,10$ \\
\hline $\begin{array}{l}\text { Wear degree of } \\
\text { fixed assets }\end{array}$ & 0,57 & $-0,04$ & $-0,33$ & $-0,17$ & 0,05 & 0,04 & 0,15 & $-0,61$ & 0,37 & 0,80 \\
\hline $\begin{array}{l}\text { Passengers } \\
\text { transported by } \\
\text { air }\end{array}$ & 0,72 & 0,47 & 0,46 & 0,50 & 0,44 & 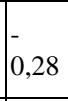 & $-0,40$ & 0,09 & 0,12 & $-0,30$ \\
\hline $\begin{array}{l}\text { Passengers } \\
\text { transported by } \\
\text { road }\end{array}$ & 0,91 & 0,84 & 0,72 & 0,62 & 0,56 & 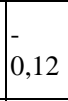 & $-0,01$ & $-0,18$ & $-0,02$ & 0,62 \\
\hline $\begin{array}{l}\text { Freight traffic } \\
\text { volume } \quad \text { by } \\
\text { inland } \\
\text { waterway } \\
\text { transport }\end{array}$ & 0,09 & $-0,74$ & $-0,13$ & 0,75 & 0,24 & 0,04 & $-0,63$ & 0,02 & 0,53 & 0,09 \\
\hline $\begin{array}{l}\text { Freight traffic } \\
\text { volume by air }\end{array}$ & 0,18 & $-0,58$ & $-0,57$ & $-0,27$ & 0,49 & 0,04 & $-0,51$ & $-0,17$ & $-0,40$ & 0,26 \\
\hline $\begin{array}{l}\text { Freight traffic } \\
\text { tariff indices }\end{array}$ & $\begin{array}{l}- \\
0,75 \\
\end{array}$ & 0,47 & $-0,12$ & $-0,10$ & 0,33 & 0,84 & 0,49 & $-0,18$ & $-0,11$ & 0,36 \\
\hline Price index & 0,72 & 0,81 & 0,44 & 0,51 & 0,22 & $\begin{array}{l}- \\
0,45 \\
\end{array}$ & 0,64 & $-0,54$ & 0,60 & $-0,60$ \\
\hline Gain, loss & 0,51 & $-0,70$ & $-0,11$ & $-0,29$ & 0,03 & 0,16 & $-0,33$ & 0,49 & $-0,68$ & 0,44 \\
\hline $\begin{array}{l}\text { Proportion of } \\
\text { unprofitable } \\
\text { enterprises }\end{array}$ & 0,65 & 0,34 & 0,11 & $-0,04$ & 0,21 & 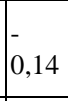 & $-0,26$ & $-0,16$ & $-0,27$ & $-0,15$ \\
\hline Investments & 0,50 & 0,11 & $-0,48$ & $-0,20$ & 0,52 & $-\overline{0}, 12$ & $-0,14$ & $-0,56$ & $-0,44$ & 0,59 \\
\hline $\begin{array}{l}\text { Labour } \\
\text { efficiency in } \\
\text { comparable } \\
2015 \text { prices }\end{array}$ & 0,62 & 0,40 & 0,32 & $-0,10$ & $-0,47$ & $-\overline{0} \mid$ & $-0,23$ & 0,02 & 0,05 & $-0,48$ \\
\hline $\begin{array}{l}\text { Total number } \\
\text { of coefficients } \\
\text { with a value } \\
\text { greater than } 0.5\end{array}$ & 11 & 9 & 6 & 8 & 6 & 3 & 4 & 5 & 4 & 5 \\
\hline
\end{tabular}

a. Sources: (Rosstat, 2005-2015) and authors' calculations.

The indicators "Value Added", "Number of Economic Entities", "Average Monthly Nominal Wage" and "Fixed Assets Costs" have the highest autocorrelation values with the past years; therefore, they are characterized by path dependence and vary from year to year very slight.

Negative path dependence is traced in the indicators "Freight Traffic Tariff Indices" with a 1-year lag and "Freight Inland Waterway Traffic Volume" with a 2-year time lag.

By absolute values, the most numerous coefficients with a value greater than 0.5 (i.e strong relation) account for a 1-year time lag. By incremental value, the most numerous coefficients account for a 5-year time lag, as well as a 3-year time lag with a negative dependence, i.e. high 3 -year-old values result in current low values. Therefore, a quite widespread dependence on the last year's indicators and the 5-year negative internal cycle are observed in the transport industry development.

Besides transport, communication is some of the most important components of the infrastructure complex. It is inextricably connected with information and technical facilities, therefore it is considered in conjunction with these indicators in 
the Information and Communication Technologies industry (hereinafter "ICT").

This industry, both in the KMAO - Yugra and within Russia at large, is of applied nature and is not classified as a separate OKVED (Russian Classification of Economic Activities) by the Russian Federal State Statistics Service. In this regard, path dependence of the economic industry evolution is studied using quantitative characteristics of the industry. Table 7 shows autocorrelation coefficients by key indicators for ICT industry.

TABLE II. AUTOCORRELATION COEFFICIENTS BY KEY INDICATORS FOR ICT SECTOR

\begin{tabular}{|c|c|c|c|c|c|c|c|c|c|c|}
\hline \multirow{2}{*}{ Indicators } & \multicolumn{5}{|c|}{$\begin{array}{c}\text { By absolute value of } \\
\text { indicator with a shift (lag) }\end{array}$} & \multicolumn{5}{|c|}{$\begin{array}{l}\text { By incremental value of } \\
\text { indicator with a shift (lag) }\end{array}$} \\
\hline & \begin{tabular}{|c|}
1 \\
year
\end{tabular} & \begin{tabular}{|c|}
2 \\
years
\end{tabular} & \begin{tabular}{|c|}
3 \\
years \\
\end{tabular} & \begin{tabular}{|c|}
4 \\
years \\
\end{tabular} & \begin{tabular}{|c|}
5 \\
years \\
\end{tabular} & $\begin{array}{c}1 \\
\text { year }\end{array}$ & \begin{tabular}{|c|}
2 \\
years
\end{tabular} & \begin{tabular}{|c|}
3 \\
years \\
\end{tabular} & \begin{tabular}{|c|}
4 \\
years
\end{tabular} & \begin{tabular}{|c|}
5 \\
years
\end{tabular} \\
\hline $\begin{array}{l}\text { Communication } \\
\text { services volume } \\
\text { rendered to the } \\
\text { public, per capita }\end{array}$ & 0.95 & 0.88 & 0.84 & 0.69 & 0.41 & 0.41 & 0.07 & 0.10 & -0.15 & 0.52 \\
\hline $\begin{array}{l}\text { Public networked } \\
\text { home telephone } \\
\text { sets available per } \\
1000 \text { urban } \\
\text { population }\end{array}$ & 0.99 & 0.98 & 0.96 & 0.95 & 0.94 & 0.88 & 0.82 & 0.66 & 0.51 & 0.33 \\
\hline $\begin{array}{l}\text { Public networked } \\
\text { home telephone } \\
\text { sets available per } \\
1000 \text { rural } \\
\text { population }\end{array}$ & 0.75 & -0.03 & -0.52 & -0.70 & -0.74 & 0.97 & 0.89 & 0.66 & 0.39 & 0.72 \\
\hline Total ICT costs & 0.77 & 0.54 & 0.39 & 0.19 & -0.08 & 0.06 & -0.31 & 0.35 & -0.05 & -0.14 \\
\hline $\begin{array}{l}\text { Internet use in } \\
\text { organizations }\end{array}$ & 0.89 & 0.79 & 0.73 & 0.87 & 0.85 & 0.02 & 0.01 & 0.05 & 0.12 & 0.24 \\
\hline $\begin{array}{l}\text { Organizations } \\
\text { with a website }\end{array}$ & 0.88 & 0.86 & 0.71 & 0.82 & 0.83 & - & 0.34 & -0.78 & 0.62 & 0.41 \\
\hline $\begin{array}{lr}\text { Number of } & \text { PCs } \\
\text { per } & 100 \\
\text { employees } & \\
\end{array}$ & 0.95 & 0.95 & 0.91 & 0.88 & 0.84 & 0.53 & 0.31 & -0.29 & 0.13 & -0.80 \\
\hline $\begin{array}{lrr}\begin{array}{l}\text { Number } \\
\text { of }\end{array} & \text { PCs } \\
\text { with } & \text { Internet } \\
\text { access per } & 100 \\
\text { employees } & \\
\end{array}$ & 0.95 & 0.89 & 0.90 & 0.91 & 0.93 & $-\overline{-}$ & -0.58 & 0.05 & 0.49 & 0.62 \\
\hline $\begin{array}{lr}\text { Average } & \text { annual } \\
\text { number } & \text { of } \\
\text { employees } & \\
\end{array}$ & 0.83 & 0.72 & 0.68 & 0.63 & 0.03 & $-\overline{-}-29$ & -0.09 & 0.04 & 0.57 & -0.79 \\
\hline $\begin{array}{l}\text { Total number of } \\
\text { coefficients with } \\
\text { a value greater } \\
\text { than } 0.5\end{array}$ & 9 & 8 & 8 & 8 & 8 & 3 & 3 & 3 & 3 & 5 \\
\hline
\end{tabular}

b. Sources: (Rosstat, 2005-2015) and authors' calculations.

All the presented indicators, except for the "ICT costs", have quite high autocorrelation coefficients with the past years, should one considers them in absolute values. These indicators are characterized by path dependence and vary from year to year very slightly. When studying the indicators autocorrelation by the incremental value, a heavy dependence is observed in the indicator "Home Telephone Sets Available ", both within urban and rural areas.

It shows that the most numerous autocorrelation coefficients with a value greater than 0.5 , when studied by absolute values, account for 1-4 year time lags. This indicates a rather strong relation with mostly positive dependence. The most numerous autocorrelation coefficients with a value greater than 0.5 , when studied by incremental value, account for a 5-year time lag. This is obviously evident for all the indicators, except for such as: "Home Telephone Sets Available in Urban Area", "Internet Use In Organizations", "Organizations With a Website". Thus, we can argue that there are no obvious internal cycles in the ICT industry development, but there is sustainable growth.

As stated above, the infrastructure complex includes the tertiary industry comprising the most important economic link - financial and credit sector. Major financing of economic growth and an investment component is carried out through its elements.

Due to the fact that the financial sector does not hold leading positions in the Khanty-Mansi Autonomous Okrug, letting the oil and gas production, technological innovation and investment industries top the rating, there is obviously no question of the industry's past indicators affecting its future performance. The financial industry has no capital investments as such, for it is missing production activity; the industry belongs to the financial services sector. We calculated autocorrelation coefficients to comprehend the degree of industry's dependence on indicators of the past periods (Table 8)

TABLE III. AUTOCORRELATION COEFFICIENTS BY KEY INDICATORS FOR FINANCIAL SECTOR

\begin{tabular}{|c|c|c|c|c|c|c|c|c|c|c|}
\hline \multirow[t]{2}{*}{ Indicators } & \multicolumn{5}{|c|}{$\begin{array}{c}\text { By absolute value of } \\
\text { indicator with a shift (lag) }\end{array}$} & \multicolumn{5}{|c|}{$\begin{array}{l}\text { By incremental value of } \\
\text { indicator with a shift (lag) }\end{array}$} \\
\hline & $\begin{array}{c}1 \\
\text { year }\end{array}$ & $\begin{array}{c}2 \\
\text { year } \\
s\end{array}$ & $\begin{array}{c}3 \\
\text { year } \\
s\end{array}$ & $\begin{array}{c}4 \\
y e a r \\
s\end{array}$ & $\begin{array}{c}5 \\
\text { year } \\
s\end{array}$ & $\begin{array}{c}1 \\
\text { year }\end{array}$ & $\begin{array}{c}2 \\
\text { year } \\
s\end{array}$ & $\begin{array}{c}3 \\
\text { year } \\
s\end{array}$ & $\begin{array}{c}4 \\
\text { year } \\
s\end{array}$ & $\begin{array}{c}5 \\
\text { year } \\
s\end{array}$ \\
\hline $\begin{array}{l}\text { Share in } \\
\text { GRP }\end{array}$ & $\begin{array}{l}0,1 \\
3\end{array}$ & 0,17 & $\overline{0}-43$ & 0,38 & 0,78 & $\begin{array}{l}0,2 \\
1\end{array}$ & $\overline{0}-\overline{33}$ & 0,31 & $-\overline{0}$ & 0,49 \\
\hline $\begin{array}{l}\text { Number of } \\
\text { enterprises }\end{array}$ & $\begin{array}{l}0,7 \\
1\end{array}$ & 0,83 & 0,76 & 0,65 & 0,89 & $\begin{array}{l}0,2 \\
6\end{array}$ & $\overline{0}, 21$ & 0,26 & $-\overline{0}-55$ & 0,45 \\
\hline $\begin{array}{l}\text { Number of } \\
\text { employed }\end{array}$ & $\begin{array}{l}0,9 \\
1\end{array}$ & 0,94 & 0,89 & 0,33 & 0,72 & $\begin{array}{l}0,7 \\
1\end{array}$ & 0,25 & 0.00 & $-\overline{0}$ & 0,32 \\
\hline $\begin{array}{l}\text { Number of } \\
\text { unprofitable } \\
\text { enterprises }\end{array}$ & $\begin{array}{l}- \\
0,2 \\
1\end{array}$ & 0,12 & 0,48 & $\overline{-}-25$ & 0,39 & $\begin{array}{l}0,6 \\
7\end{array}$ & 0,25 & $-\overline{0}, 37$ & 0,74 & 0,17 \\
\hline Investments & $\begin{array}{l}0,0 \\
1\end{array}$ & 0,87 & $\begin{array}{l}- \\
0,16\end{array}$ & $\begin{array}{l}- \\
0,72\end{array}$ & $-\overline{0}-86$ & $\begin{array}{l}- \\
0,1 \\
6\end{array}$ & $\begin{array}{l}- \\
0,29\end{array}$ & 0,78 & 0,51 & $-\overline{0}$ \\
\hline $\begin{array}{l}\text { Overdue } \\
\text { accounts } \\
\text { payable } \\
\text { amount }\end{array}$ & $\begin{array}{l}0,5 \\
1\end{array}$ & $\begin{array}{l}- \\
0,81\end{array}$ & 0,63 & 0,16 & 0,69 & $\begin{array}{l}- \\
0,1 \\
2\end{array}$ & 0,20 & 0,35 & $-\overline{0}-13$ & 0,13 \\
\hline $\begin{array}{l}\text { Overdue } \\
\text { accounts } \\
\text { receivable } \\
\text { amount } \\
\end{array}$ & $\begin{array}{l}- \\
0,3 \\
1\end{array}$ & $\begin{array}{l}- \\
0,71\end{array}$ & $\overline{-}-$ & 0,12 & 0,03 & $\begin{array}{l}- \\
0,3 \\
6\end{array}$ & $\begin{array}{l}- \\
0,14\end{array}$ & 0,14 & $-\overline{-}$ & 0,47 \\
\hline $\begin{array}{l}\text { Credit } \\
\text { indebtedness } \\
\text {, RUB }\end{array}$ & $\begin{array}{l}- \\
0,3 \\
2\end{array}$ & 0,26 & 0,55 & 0,35 & $\overline{-}, 22$ & $\begin{array}{l}- \\
0,4 \\
2\end{array}$ & 0,36 & 0,22 & 0,06 & $\begin{array}{l}- \\
0,41\end{array}$ \\
\hline $\begin{array}{l}\text { Credit } \\
\text { indebtedness } \\
\text {, FCY }\end{array}$ & $\begin{array}{l}0,4 \\
1\end{array}$ & 0,45 & 0,86 & $\overline{-}_{0,11}$ & 0,71 & $\begin{array}{l}- \\
0,2 \\
3\end{array}$ & 0,19 & 0,10 & $\begin{array}{l}- \\
0,82\end{array}$ & 0,35 \\
\hline $\begin{array}{l}\text { Total } \\
\text { number of } \\
\text { coefficients } \\
\text { with a value } \\
\text { greater than } \\
0.5\end{array}$ & 3 & 5 & 5 & 2 & 6 & 2 & 0 & 2 & 5 & 0 \\
\hline
\end{tabular}

c. Sources: (Rosstat, 2005-2015) and authors' calculations.

The indicators "Number of Enterprises", "Number of Employed" and "Investments" have high autocorrelation 
coefficients compared to the previous periods, i.e. these indicators are characterized by high-level path dependence and their changes are minor with each period.

It is also evident that the most numerous autocorrelation coefficients with a value greater than 0.5 (indicating a high level of dependence), account for a 5-year time lag by indicator's absolute values and a 4-year time lag by incremental value. Moreover, absolute values show mostly positive dependence, i.e. high indicators of the current period result in high indicators of future periods. Negative dependence by incremental value means that high 4-year-old indicators result in current low indicators. In particular, it refers to the GRP share, the number of enterprises, the number of employed people, investments and overdue accounts.

Thus, we can claim that the 4-year internal cycle is evident in the financial industry development in the KMAO - Yugra.

At present, trade and small business are among the most progressive types of activity of the infrastructure complex affecting all population sections and ensuring the effective functioning of the market economy entities. We calculated autocorrelation coefficients to comprehend the degree of path dependence of this industry. In view of the abundance of statistical data published by Rosstat, the most important indicators have been selected, in the authors' opinion, characterizing the industry in question (Table 9).

TABLE IV. AUTOCORRELATION COEFFICIENTS BY KEY INDICATORS FOR TRADE AND SMALL BUSINESS SECTOR

\begin{tabular}{|c|c|c|c|c|c|c|c|c|c|c|}
\hline \multirow[t]{2}{*}{ Indicators } & \multicolumn{5}{|c|}{$\begin{array}{c}\text { By absolute value of } \\
\text { indicator with a shift (lag) }\end{array}$} & \multicolumn{5}{|c|}{$\begin{array}{l}\text { By incremental value of } \\
\text { indicator with a shift (lag) }\end{array}$} \\
\hline & $\begin{array}{c}1 \\
\text { year }\end{array}$ & $\begin{array}{c}2 \\
\text { year } \\
s\end{array}$ & $\begin{array}{c}3 \\
\text { year } \\
s\end{array}$ & $\begin{array}{c}4 \\
\text { year } \\
s\end{array}$ & $\begin{array}{c}5 \\
\text { year } \\
s\end{array}$ & $\begin{array}{c}1 \\
\text { year }\end{array}$ & $\begin{array}{c}2 \\
\text { year } \\
s\end{array}$ & \begin{tabular}{|c|}
3 \\
year \\
$s$
\end{tabular} & $\begin{array}{c}4 \\
\text { year } \\
s\end{array}$ & $\begin{array}{c}5 \\
\text { year } \\
s\end{array}$ \\
\hline $\begin{array}{l}\text { Industry's } \\
\text { GRP }\end{array}$ & $\begin{array}{l}0.9 \\
5\end{array}$ & 0.87 & 0.77 & 0.65 & 0.65 & $\begin{array}{l}0.0 \\
6\end{array}$ & 0.07 & $-\overline{0}$ & $\overline{-}-4$ & 0.34 \\
\hline $\begin{array}{l}\text { Number of } \\
\text { small } \\
\text { enterprises }\end{array}$ & $\begin{array}{l}0.9 \\
5\end{array}$ & 0.88 & 0.79 & 0.70 & 0.77 & $\begin{array}{l}0.0 \\
1\end{array}$ & $\overline{0}-33$ & $\begin{array}{l}- \\
0.46\end{array}$ & $-\overline{0}$ & 0.40 \\
\hline $\begin{array}{l}\text { Average } \\
\text { staff } \\
\text { number in } \\
\text { small } \\
\text { enterprises }\end{array}$ & $\begin{array}{l}0.9 \\
4\end{array}$ & 0.84 & 0.64 & 0.38 & $-\overline{0}$ & $\begin{array}{l}0.2 \\
2\end{array}$ & 0.33 & - & - & - \\
\hline $\begin{array}{l}\text { Small } \\
\text { enterprises } \\
\text { turnover }\end{array}$ & $\begin{array}{l}0.9 \\
3\end{array}$ & 0.91 & 0.85 & 0.88 & 0.82 & $\begin{array}{l}- \\
0.2 \\
6\end{array}$ & 0.11 & - & 0.42 & - \\
\hline $\begin{array}{l}\text { Number of } \\
\text { commercia } \\
1 \\
\text { enterprises }\end{array}$ & $\begin{array}{l}0.5 \\
6\end{array}$ & 0.22 & $-\overline{0}$ & $\overline{-}-4$ & $\overline{-}-34$ & $\begin{array}{l}- \\
0.0 \\
7\end{array}$ & - & - & 0.01 & - \\
\hline $\begin{array}{l}\text { Average } \\
\text { staff } \\
\text { number in } \\
\text { commercia } \\
1 \\
\text { enterprises }\end{array}$ & $\begin{array}{l}0.7 \\
5\end{array}$ & 0.57 & 0.28 & 0.07 & 0.34 & $\begin{array}{l}- \\
0.2 \\
3\end{array}$ & 0.03 & $-\overline{0}$ & $\begin{array}{l}- \\
0.21\end{array}$ & 0.43 \\
\hline $\begin{array}{l}\text { Retail } \\
\text { turnover } \\
\text { per capita } \\
\end{array}$ & $\begin{array}{l}0.8 \\
8\end{array}$ & 0.54 & 0.24 & 0.65 & 0.96 & $\begin{array}{l}0.3 \\
1\end{array}$ & - & - & - & 0.71 \\
\hline $\begin{array}{l}\text { Fixed } \\
\text { assets costs }\end{array}$ & $\begin{array}{l}0.9 \\
7\end{array}$ & 0.93 & 0.94 & 0.92 & 0.89 & $\begin{array}{l}- \\
0.0 \\
7\end{array}$ & 0.18 & - & $\begin{array}{l}- \\
0.48\end{array}$ & - \\
\hline
\end{tabular}

\begin{tabular}{|c|c|c|c|c|c|c|c|c|c|c|}
\hline $\begin{array}{l}\text { Trade } \\
\text { turnover }\end{array}$ & $\begin{array}{l}0.9 \\
8\end{array}$ & 0.97 & 0.97 & 0.97 & 0.97 & $\begin{array}{l}0.3 \\
2 \\
\end{array}$ & $\begin{array}{l}- \\
0.22\end{array}$ & $\begin{array}{l}- \\
0.12\end{array}$ & 0.08 & 0.47 \\
\hline $\begin{array}{l}\text { Investment } \\
\mathrm{s}\end{array}$ & $\begin{array}{l}0.7 \\
3\end{array}$ & 0.79 & 0.75 & 0.40 & 0.77 & $\begin{array}{l}- \\
0.4 \\
2\end{array}$ & 0.17 & 0.27 & $\begin{array}{l}- \\
0.32\end{array}$ & 0.60 \\
\hline Gain, loss & $\begin{array}{l}0.0 \\
3\end{array}$ & $\overline{-}-03$ & 0.24 & $\overline{0}-23$ & 0.06 & $\begin{array}{l}- \\
0.5 \\
4\end{array}$ & $-\overline{0.09}$ & 0.72 & $\begin{array}{l}- \\
0.68\end{array}$ & 0.44 \\
\hline $\begin{array}{l}\text { Total } \\
\text { number of } \\
\text { coefficient } \\
\mathrm{s} \text { with a } \\
\text { value } \\
\text { greater } \\
\text { than } 0.5\end{array}$ & 10 & 9 & 7 & 6 & 7 & 1 & 0 & 5 & 3 & 2 \\
\hline
\end{tabular}

Most of the indicators presented have had high values of autocorrelation coefficients over the past years. We note that the most numerous autocorrelation coefficients with a value greater than 0.5 (indicating a quite strong relation) account for a 1 -year time lag by absolute values, and the greatest number of indicators accounts for a 3-year time lag by incremental value. The indicator "Investments" also has high values, based on the results of which, it is possible to detect periodic fluctuations in the values of this indicator with a 2-year period. In its turn, the indicators "Number of Enterprises" and "Number of Employed" have negative dependence. At the same time, the dataset dynamics of the indicator "Gain, Loss" shows no trend.

\section{CONCLUSIONS}

The autocorrelation coefficients analysis has showed that path dependence is present in most of infrastructural economic sectors. And there is a cyclical development in some of economic sectors. For instance, a 4-year internal cycle is evident in the region's financial sector development. In contrast, there is no evident cyclicity in such sectors as ICT and communications, trade and small business. At the same time, for the two latter sectors, a strong upward trend was recorded.

The correlation coefficients analysis has shown that a quite widespread dependence on last year's indicators and a 3-year negative internal cycle are observed in the infrastructure sectors, except for the ICT domain, wherein sustainable growth is evident.

Thus, the paper summarizes the analysis results of the degree of path-dependent economic sectors' evolution in the northern resource-extraction region. The authors have revealed the Khanty-Mansi Autonomous Okrug is more of a pathdependent region, posing problems for economic reforming and diversification. Accordingly, it is theoretically and practically significant to further research factors affecting the economic sectors development in the northern resource-extraction region, considering correlation dependencies between them, as well as predicting key development indicators.

\section{Acknowledgment}

The research was conducted owing to funding from the Russian Foundation for Basic Research and the Department of Education and Science of the Khanty-Mansi Autonomous Okrug-Yugra, grant No. 17-12-86010 "Long-term forecasting of the economic evolution of the resource-extraction region, 
considering path-dependence and institutional environment features (case study of the Khanty-Mansi Autonomous Okrug Yugra)".

\section{References}

[1] M. P. Bazilevsky, G. D. Gefan, On autocorrelation effects consideration in time series, Information technologies and complex systems mathematical modeling issues, 2015, p.11-22.

[2] D. Y. Zhmurko, Applying correlation analysis in the sugar agroindustrial business (part 1 - autocorrelation and partial autocorrelation), Multidisciplinary Networked Electronic Journal of Kuban State Agrarian University, 2016, No. 116, p. 1073-1109.

[3] V. F. Islamutdinov, Comparative institutional analysis as a new method to study regional specific features, Bulletin of Yugra State University, 2015, No. S4 (39), pp. 308-312.

[4] V.F. Islamutdinov, Evolution and specificity of the economic institutions of Khanty-Mansi Autonomous Okrug - Yugra, Economy of Region, 2016, vol. 12, issue 2, pp. 463-470.

[5] N.V. Katargin, A.V. Tsvetkov, Studying high-order autocorrelations in series of asset prices on the stock market, International Science Journal, 2011, No. 4, p. 38-42.

[6] E. R. Kerimova, Econometric cost-benefit analysis of credit institutions, Science and Education: Economy and Economics; Entrepreneurship; Law and Management, 2011, No. 5 (11), p. 62-68.

[7] V. E. Korolkov, E. L. Moreva, The domino theory and path dependence development: opportunities and limitations in the post-Soviet states, Advances in modern science and education, 2016, No. 10, p. 78-83.

[8] A. M. Libman, Optimal path dependence, Social sciences and modernity, 2008, No. 5, pp. 5-17.

[9] I. Rudakova, The National Strategy of Economic Growth: Path Dependence and Milestones, Bulletin of the Institute of Economics, Russian Academy of Sciences, 2013, No. 4, pp. 26-38.

[10] I. M. Shiryaev, Path dependence development and path establishing as the most important concepts in the evolutionary economics, Journal of Economic Regulation, 2013, vol. 4, No. 3, p. 103-112.

[11] T. Brekke, Regional economic change, entrepreneurship and regional path dependency in Non-Metropolitan Region, 2015. Access mode: http://www.regionalstudies.org/uploads/Thomas_Brekke.pdf

[12] A. Koren, I. Tirosh, N. Barkai, Autocorrelation analysis reveals widespread spatial biases in microarray experiments, BMC Genomics, $2007 . \quad$ Access mode: https://bmcgenomics.biomedcentral.com/articles/10.1186/1471-2164-8164

[13] R. Martin, P. Sunley, Path dependence and regional economic evolution, Journal of Economic Geography, 2006, no. 6, № 4, pp. 395-437.

[14] D. North, J.J. Wallis, S.E. Webb, B. Weingast, Limited Access Orders in the Developing World: A New Approach to the Problems of Development, World Bank Policy Research Working Paper, 2007. Access mode:

http://econweb.umd.edu/ wallis/MyPapers/Limted_Access_Orders_in_t he_Developing_WorldWPS4359.pdf

[15] A. Peters, Statistics for Analysis of Experimental Data, Champaign: AEESP, IL, 2001.

[16] P.J. Tsai, M.L. Lin, C.M. Chu, C.H. Perng, Spatial autocorrelation analysis of health care hotspots in Taiwan in 2006, BMC Public Health, 2009 . Access mode: https://bmcpublichealth.biomedcentral.com/articles/10.1186/1471-24589-464 